\title{
Niche modeling remarks of Luidia senegalensis (Lamarck, 1816) (Asteroidea, Luidiidae) after 30 years of its first capture in the northeastern Brazilian coast
}

\author{
Carolina T. Puppin-Gonçalves ${ }^{1}$, Matheus Arthur L. Rocha ${ }^{1}$, Carlos E.R.D. Alencar ${ }^{1,2}$ \\ Sávio A.S.N. Moraes ${ }^{1}$, Paulo V.N. Araújo ${ }^{1,3}$ \& Fúlvio A.M. Freire ${ }^{1}$ \\ ${ }^{1}$ Laboratório de Ecologia e Evolução de Crustáceos (LABEEC), Departamento de Biologia \\ Ecologia e Zoologia, Centro de Biociências, Universidade Federal do Rio Grande do Norte (UFRN) \\ Campus Universitário Lagoa Nova, Natal, Brasil \\ ${ }^{2}$ Departamento de Ciências Biológicas, Universidade Regional do Cariri (URCA) Campus Pimenta \\ Crato, Brasil \\ ${ }^{3}$ Instituto Federal de Educação, Ciência e Tecnologia do Rio Grande do Norte (IFRN) \\ Campus Macau, Macau, Brasil \\ Corresponding author: Carolina T. Puppin-Gonçalves (carolpuppin@gmail.com)
}

\begin{abstract}
After more than 30 years of species' first capture on the Brazilian northeast coast, we report the second occurrence of the starfish Luidia senegalensis with niche modeling remarks on its distribution. Bottom trawl net collected specimens with artisanal fishery boat in Rio Grande do Norte State, northeast Brazil. It was noted the existence of a large number of regions, with high suitability for the occurrence of this species, in South America taking into account the ecological niche modeling, when compared to North and Central American continents. Benthic salinity range, calcite, and benthic minimum temperature were the most relevant for modeling. The northeastern, eastern, and southeastern Brazil ecoregions showed the most considerable amount of areas with high suitability for L. senegalensis. The niche modeling revealed essential aspects of the species and its distribution, raising concerns with regards to its future stability.
\end{abstract}

Keywords: Luidia senegalensis; Echinodermata; starfish; by-catch; northeastern ecoregion; Rio Grande do Norte; Brazil

The taxon Echinodermata Bruguière, 1791, has relative importance in benthic community structuration due to its broad niche occupancy radiation, tolerance to salinity and temperature variations, as well as other abiotic factors that present themselves as limiting factors for the survivor of aquatic organisms (Gómez, 1987). Echinoderms may be found in many distinct habitats since intertidal to deep-sea regions with restricted physical and chemical environmental variation (Hyman, 1955; Hadel et al., 1999).

In Brazil, there are approximately 300 species belonging to the phylum Echinodermata (Manso et al., 2008), while worldwide, there is an estimate of 7,000 species (Pawson, 2007). The specialized literature encompasses, mainly, inquiries of species' occurrences and, in the background, studies concerning population aspects (Krau, 1950; Brito, 1971; Hadel et al., 1999; Netto et al., 2005; Ventura et al., 2006). In the northeast region of Brazil, biological and population features of distinct Echinodermata species are barely known, and, due to it, they are still considered to hold the evaluation of conservation status as "Non-evaluated" (Amaral et al., 2008).

The family Luidiidae Verrill, 1899, has a wide distribution along the American coastline, being its representatives usually found associated with muddy substrates with a high proportion of silt and clay (Clark $\&$ Downey, 1992). Their primary behavioral habit is to keep themselves partially buried in environments with mollusks, their primary prey item (Manso et al., 2008). 
In the South American coast, six species of the family Luidiidae have been registered, being the nine-armed starfish Luidia senegalensis (Lamark, 1816) one of them. Its distribution is known from Santa Catarina (Brazil) to Florida (USA), and, in Brazil, it occurs from Santa Catarina (south) to Amapá (north) (Amaral et al., 2008). This species was already registered in Rio Grande do Norte State (Gondim et al., 2014). However, the specimens described in the study were collected in 1980 and 1982, in Ponta do Mel municipality and Timbau Beach, which we believe the correct beach name is "Tibau." Therefore, there is a time gap of almost 40 years with no records of this species for the coast of Rio Grande do Norte State.

L. senegalensis is an important predator that feeds on other aquatic invertebrates, including other asteroids (Halpern, 1970; Lawrence, 2013). In Brazil, the Environmental Ministry (MMA), the central government agency responsible for national environmental policies, categorizes this species as threatened, since it is captured continuously as by-catch in shrimp trawling (Amaral et al., 2008). This study aims to perform a complete revision of the species occurrence registry and build an updated map of distribution considering the importance of this species for coastal ecosystems and the substantial time without its register, beyond the inconsistency of beach name of the first record. Also, we evaluated the potential suitability of this species through an ecological niche modeling using the maximum entropy algorithm (Maxent) to provide complementary data and observa-tions to this first record of the species in Rio Grande do Norte coast since the ' 80 s.

The specimens were collected in the shallow continental shelf of Rio Grande do Norte (RN) State, northeast Brazil, between 2013 and 2015. The fieldwork was realized in the northern (Porto do Mangue, and Ponta do Mel Municipality) and southern (Baia Formosa Municipality) areas of the state to explore the benthic biodiversity of the region. In Porto do Mangue, the sampling was quarterly, according to rainy and dry seasons determined by a historical compilation of rainfall data in 10 years (1992-2012) (EMPARN - Empresa de Pesquisa Agropecuária do Rio Grande do Norte, Brazil). Therefore, there were two samplings by season (dry, March-May and JuneAugust; and rainy, September-November and December-February) by year (Alencar et al., 2017). Sampling was occasional in Ponta do Mel through escorting a beach trawling in August 2015. In Baia Formosa, samplings were monthly (from March 2013 to February 2015) according to a sampling effort described by Alencar et al. (2014).
Georeferenced samplings (Figs. 1c-d) were done using a trawl net ( $25 \mathrm{~mm}$ between opposite angles) in an artisanal fishery boat, each time dragged for $20 \mathrm{~min}$, except in Ponta do Mel. In each sampling location, individuals were set apart accordingly to their morphotypes, cryoanesthetized, identified, measured (diameter between arms), and fixed in ethanol 100\%. Lastly, specimens were cataloged to the Invertebrate Collection of Universidade Federal do Rio Grande do Norte (voucher numbers: GEEFAA/UFRN 884, 885 and 886).

Data on species' records were acquired through databases, such as Species Link [http://splink.cria.org. $\mathrm{br} /$ ] and Global Biodiversity Information Facility (GBIF) [http://www.gbif. org/], to build a species distribution modeling, besides specialized literature (papers, reports). Data were evaluated regarding reliability and, when needed, some were excluded due to information repetition and doubtful locations. All species records were analyzed according to Alencar et al. (2017) procedures.

The marine environmental layers used in the species distribution modeling were obtained from the databases Bio-ORACLE [http://www.oracle.ugent.be/] and MARSPEC [http://www.marspec.org/]. At first, correlations between variables were inspected, and variable inflation factor and environmental factors that exhibited correlation above $80 \%$ to other variables were removed from the analysis (Pearson's $r<0.8$ ) due to among-factors collinearity. Afterward, the decisionmaking of the adequate variable for modeling also took into account the species' biology. Therefore, the following nine variables were selected for the final model development: benthic salinity range (mean depth); surface salinity range, surface mean calcite concentration $\left(\mathrm{mol} \mathrm{m}^{-3}\right)$; benthic minimum temperature $\left({ }^{\circ} \mathrm{C}\right)$ (mean depth); surface mean dissolved oxygen $\left(\mathrm{mol} \mathrm{m} \mathrm{m}^{-3}\right)$; surface maximum current velocity $(\mathrm{m})$, east/west aspects (radians), bathymetric slope (degrees), and annual range in sea surface salinity.

The ecological niche modeling was estimated through the maximum entropy algorithm. The algorithm uses optimization procedures to relate species' presence and environmental characteristics (Stockwell \& Peters, 1999), predicting the potential environmental suitability for their occurrences (Phillips \& Dudík, 2008) through known distribution data. We analyzed ROCReceiver Operating Characteristics (sensitivity, proportion between true presences and total presences, to the complement of specificity, proportion between true absences and total of absences -Phillips et al., 2006) and AUC-Area under the curve (varies from zero to one, indicating model performance -Fielding \& Bell, 1997). Raster layers of both databases were cropped to the study area, and only occurrence data $<5$ arcmins 

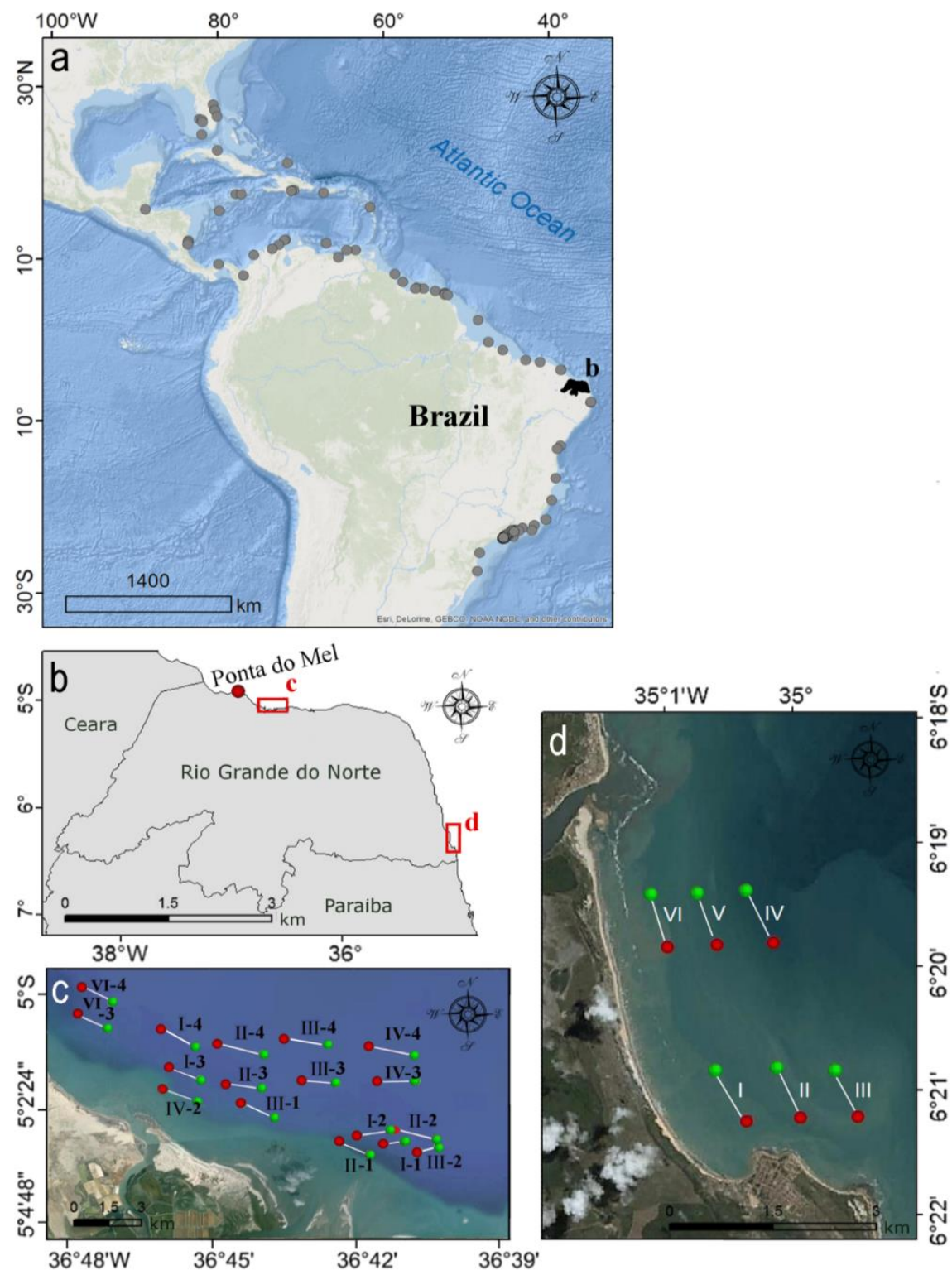

Figure 1. The starfish Luidia senegalensis. a) Geographical distribution. From GBIF data and literature review, b) sampling area in the Rio Grande do Norte State, c) Porto do Mangue Municipality, roman numerals represent the sampling transects (transects: I, II, III, IV, V and VI), and arabic numerals represent seasonality (1: July, 2013 and August, 2014, 2: November, 2013 and February, 2015, 3: February, 2014 and May, 2015, 4: May, 2014 and June, 2015), d) Baia Formosa municipality, roman numerals represent the sampling transects (transects: I, II, III, IV, V and VI) repeated for 48 months.

$\left(0.083^{\circ} ; \sim 10 \times 0 \mathrm{~km}\right)$ of spatial resolution was used. The default parameters were used to build the model, and occurrence duplicates were removed. The model was developed based on 20 bootstrap replicas, a random selection of $25 \%$ of species' records for the model evaluation, and $75 \%$ for its calibration. Through numerical results of the model, it was generated a potential distribution map regarding environmental suitability and the "response curve" for each abiotic variable. Besides, Jackknife's permutations were also performed to detail the contribution importance of model variables individually and synergistically. The model was built through $\mathrm{R}$ software using a Dismo package (Hijmans et al., 2017; R Core Team, 2016).

We examined three adult specimens (136.1, 193.8, and $109.0 \mathrm{~mm}$ ), Porto do Mangue, RN (voucher: GEEFAA-884); two adult specimens (154.6 and 150.5 $\mathrm{mm}$ ), Ponta do Mel, RN (GEEFAA-885); and two adult specimens (111.8 and $148.7 \mathrm{~mm}$ ), Baia Formosa, RN (GEEFAA-886). One adult specimen, Cabo Branco 


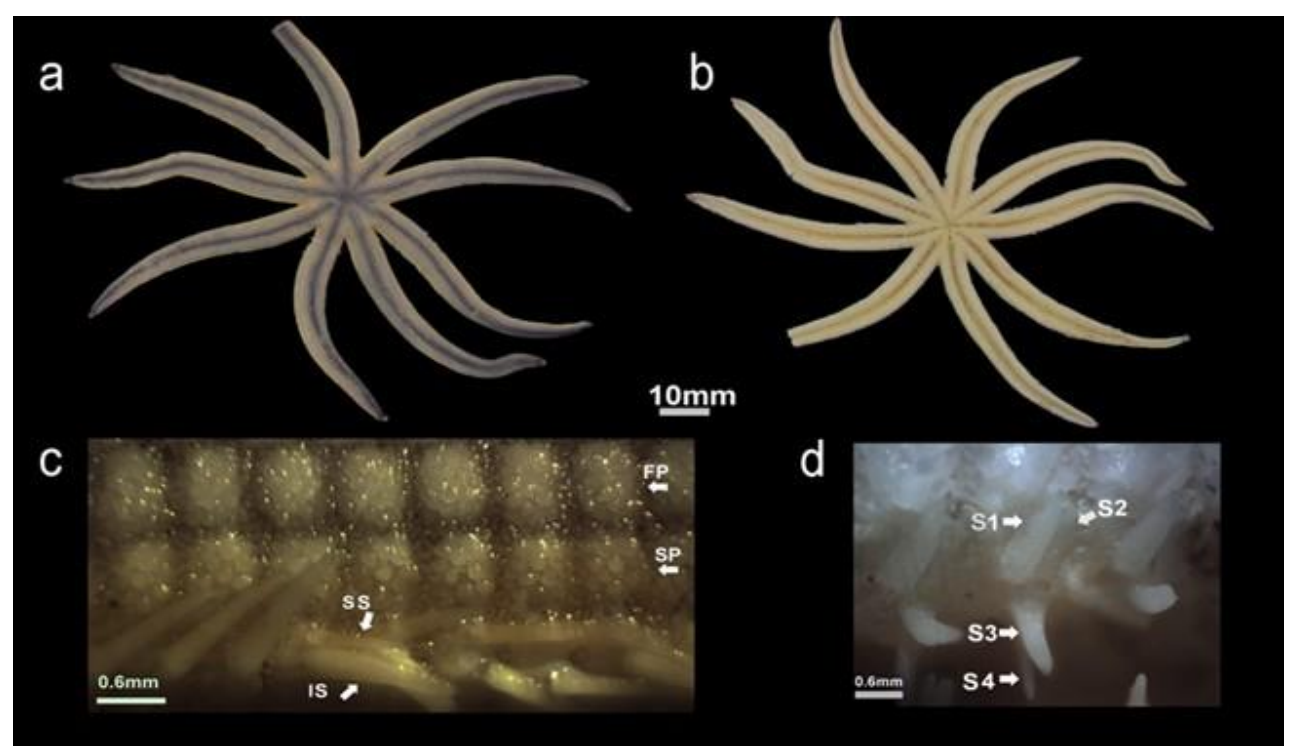

Figure 2. Luidia senegalensis macrostructure diagnosis. a) Aboral view of starfish, b) oral view of starfish, c) an extended view of the lateral portion of the arm, d) spines of the adambulacral plate. FP: first regular line of square-shaped paxilae, SP: second regular line of square-shaped paxilae, SS: the superior spine, IS: the inferior spine, S1: spine number one, S2: spine number two, S3: spine number three, S4: spine number four.

Beach, João Pessoa, Paraiba, 1978-2007, AI Gondim det. (UFPB-ECH-1168) was used as compared material. The specimens of $L$. senegalensis has from 7 to 9 elongated arms (Figs. 2a-b) (mostly 9), with two regular lateral lines of square-shaped paxilae (Fig. 2c). Inferomarginal figs with two spines, being the inferior larger than the superior. Adambulacral figs with four spines (Fig. 2d).

One hundred and eighty occurrence points of $L$. senegalensis were compiled after the exclusion of nontrustworthy data. The southernmost occurrence in America is in Santa Catarina State (Brazil), and the northernmost in Florida State (USA) (Fig. 1a). The highest concentration of records was in South America, being the majority in the Brazilian northeast and southeast region. Besides, there were observed many occurrence gaps for northeast Brazil. These gaps were mainly in the west coast of Rio Grande do Norte State and on the coast of Pernambuco, Alagoas and Sergipe states. As a result of this sampling effort, three sampling stations were added in our primary dataset for Rio Grande do Norte coast, Porto do Mangue Municipality coast (Fig. 1c), Baia Formosa Municipality (Fig. 1d), and Ponta do Mel Village, Areia Branca Municipality. When it comes to North and Central American countries, records are focused close to the Caribbean Islands and Florida.

The ecological niche modeling exhibited excellent performance in species distribution (Area under the curve $-\mathrm{AUC}=0.991$ ) and evidenced the benthic salinity range as the most influential variable for the species' distribution (58.1\% model contribution). The second most influential variable was calcite (22.8\%). However, the benthic minimum temperature was the variable with higher permutation importance $(33.6 \%)$, followed by calcite concentration $(20.5 \%)$.

The predicted distribution by the models indicated several numbers of suitable regions for the species on the South American coast (suitability >0.8). The most reliable evidence of regions with relevant suitability was northeastern, eastern (Tropical Atlantic Province), and southeastern Brazil (warm temperate southwestern Atlantic Province) ecoregions (Spalding et al., 2007). It was possible to observe that the environmental suitability of L. senegalensis decays by temperate regions' proximity (Fig. 3). There are two hypotheses for a long time without registers of this starfish species. First, the Echinodermata biodiversity and distribution of the continental shelf of Brazil are poorly studied. In the last 10 years, the number of researches involving echinoderms biodiversity has increased due to government investments in science and the obligation of environmental licensing for activities with the potential to cause environmental damages (which provides species inventories), but this number is still meager. For example, between all 1,800 worldwide known species of Asteroidea, only 77 are recorded in the Brazilian coastline (Ventura et al., 2013). Another hypothesis is based on the temporal variation of the species abundance. Since 2015, echinoderms such as starfishes and sand dollars seemed to have their abundan- 


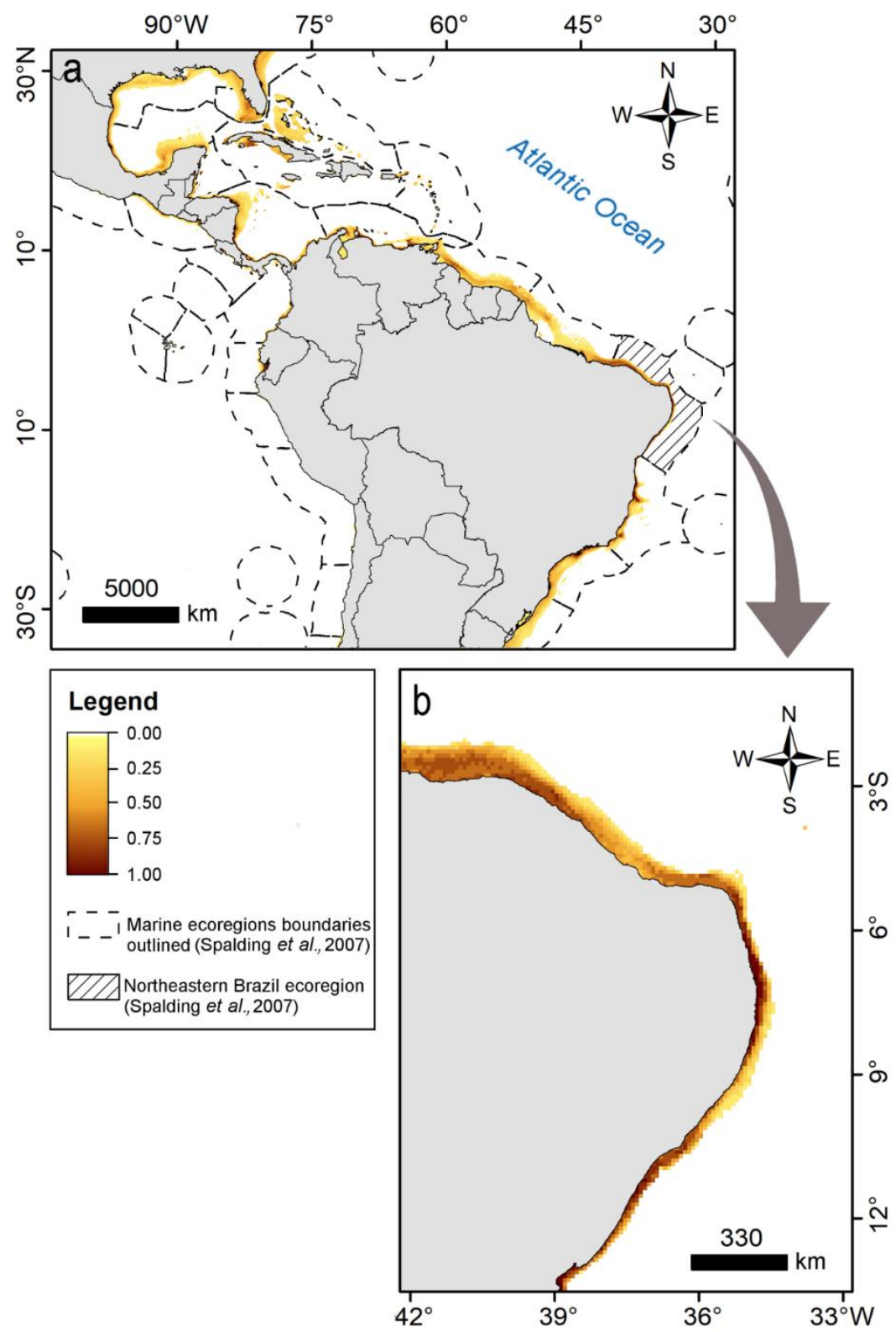

Figure 3. Luidia senegalensis potential distribution map from ecological niche modeling with present data of occurrence. a) View in scale continental (tropical America). b) Cut view of Brazilian Northeast coastal. The gradient color in legend shows the occurrence suitability of species (darker colors represent greater probabilities of specie occurring).

ce increased in Porto do Mangue Municipality (A. Cerd, pers. observation). However, the causes of this growing abundance are still unknown and need to be studied considering some singularities of the region, such as semiarid climate conditions and hypersaline estuaries.

The current distribution of $L$. senegalensis, throughout the Brazilian coast, may evidence how much this species can be tolerant to environmental physical and chemical pattern's variation, since its places of occurrence may present different characteristics, such as sediment type, depth, temperature, amongst others
(Fulan et al., 2009). Tolerance and adaptation to abiotic factors' variation capacity are limiting for many aquatic species survivals, which depends on a set of parameters to conclude their life cycle and establish in the environment (Helmuth, 2009).

The first $L$. senegalensis occurrence in Rio Grande do Norte State was recorded using samplings made in the region in the years of 1980 and 1982 (Gondim et al., 2014). However, the sampling methods or georeferenced location were not mentioned. Therefore, their valid register was virtually known. Given this 80's record, there are no published reports of this species 
sampling in the region, leaving a gap of almost 40 years. In that way, the present study records officially, with geographical consistency, the occurrence of $L$. senegalensis on coast Rio Grande do Norte state covering an extension of approximately $410 \mathrm{~km}$. In addition to the occurrence records, our results suggest that the northeastern Brazil marine ecoregion (Spalding et al., 2007) showed high suitability for the species occurrence. The marine ecoregions are areas with particular environmental characteristics, considering large-scale variations, exhibiting a highly similar fauna and ecological interactions, especially for species with lower vagility (Spalding et al., 2007). Thus, although there are variations in smaller scales, the northeastern Brazil ecoregion has adequate conditions for the species establishment. In the sampled localities' area in the present study, the suitability was between 0.75 and 1.0 (i.e., high suitability). During sampling, $L$. senegalensis was collected in practically all sampling points, with various body sizes, indicating that this species can have a stabilizing type population structure and, therefore, a strong indication of being stable in the region (C.T. Puppin-Gonçalves, S.A.S.N. Moraes and A. Cerd, pers. communication).

In the estimated potential ecological niche modeling, the primary environmental factors related to the species' environmental suitability were: benthic minimum temperature, calcite in the water column, and benthic salinity range. The minimum temperature variable of the ocean floor reflects the species occurrence since its distribution is restricted to the Atlantic Ocean tropical region (Amaral et al., 2008). With the temperate regions' proximity, the occurrence probability gradually decays until reaching its nullity in the north and south temperate regions. Thus, the minimum temperature for the species occurrence is superior to the temperatures of the other regions, which may be an indicator of favoring the establishment and significant population size in the region of Rio Grande do Norte State, northeastern Brazil ecoregion.

The variable calcite seems to reflect the physiological needs and diet of the species. Calcite is an essential mineral for ossicle formation of many echinoderms, which are constituted by $\mathrm{MgCO} 3$ compounds crystals, very often found in robust solutions (Towe, 1967). Besides, Amaral et al. (2008) highlight that calcium carbonate $(\mathrm{CaCO} 3)$, central element composing calcite, is also crucial for mollusks' shell formation, fundamental food of $L$. senegalensis. The featured position of calcite in the potential distribution model of $L$. senegalensis raises concerns given the increasing levels of atmospheric carbonic gas (CO2) on the planet. McClintock et al. (2011) demonstrated that the oceans' acidification caused by
$\mathrm{pH}$ decrease might be especially harmful to echinoderms, as the calcite can become unsaturated in approximately 100 years. The phenomenon may cause the decalcification of these organisms' structures and hinder skeleton formation, creating a substantial marine ecosystem alteration.

The salinity amplitude is an essential variable for the echinoderms since they are mostly classified as stenohaline, being sensitive to large salinity variations (Stickle \& Diehl, 1987). Species belonging to the genus Luidia occur in environments with oceanic salinity, except Luidia clathrata (Say, 1825), which can be found in brackish waters (Lawrence et al., 2013). The inquiry on geographic distribution and potential niche modeling revealed biogeographic features associated with salinity variation. The suitability for species occurrence was decreased in the regions near the mouth of great rivers such as Amazonas and São Francisco. Studies on L. clathrata have demonstrated the species' capacity to survive and reproduce at lower salinity concentrations (i.e., 17). However, there was a significant decrease in energetic rates due to the lower frequency of feeding rate, affecting the species growth (Forcucci \& Lawrence, 1986).

Moreover, Amazon and São Francisco Rivers may act as geographic barriers for this species occurrence. Amazon River sediments' plume creates a barrier for many reef fishes and other organisms (Rocha, 2003). For example, for "pluteus" larvae, this plume can be more useful for their passive swimming strategy. In this kind of larvae, there are extensions (arms, specifically for echinoderms) that act as stabilizers and favor the driving by ascending water flow; however, they are inefficient for swimming orientation and way (Forward Jr. \& Tankersley, 2001; Grünbaum \& Strathmann, 2003). Thus, given the low competence to undermine the vast amount of water coming from deltas and river mouths, adding the fact that echinoderms' larvae are stenohaline, with low survival rates to freshwater plumes that enter the ocean (Cowart et al., 2009; Allen \& Pechenik, 2010) there is a strong reinforcement to larval dispersal limitations and population structuration. The corner region of the South American continent, the Rio Grande do Norte State, has smaller rivers that cause low influence in the local coastal hydrodynamic process. Moreover, the north coast has a semiarid regime with high averages of temperature and low rainfall, where hypersaline estuaries are found, several artificial barriers (Moura et al., 2007). These characteristics, therefore, contribute to the region's suitability for the species.

This new data on the occurrence of the species, after more than three decades, together with the new the 
geographic distribution and environmental suitability information, may help future research on the biogeography, population dynamics, of macroinvertebrate community's structuration, macro-ecological distribution, and biodiversity of the benthic communities of this region. The continental shelf of Rio Grande do Norte State is still underexplored regarding its biodiversity, showing information gaps. Over the past years, new occurrences for many benthic organisms have been reported (Alencar et al., 2013, 2017; Manso et al., 2014; Gondim et al., 2015; Moraes et al., 2015) and new ecological interactions (Alencar et al., 2014), which shows that the development of scientific research involving the local marine biodiversity is required in the state. More studies and monitoring programs focused on marine faunal biodiversity are essential subsidies for future assessment plans and reevaluation of $L$. senegalensis threat status, especially on the coast of northeast Brazil, where macrofaunal diversity knowledge is scarce and needs more investment when compared to south and southeast Brazilian regions.

\section{ACKNOWLEDGMENTS}

We are grateful to Anne Isabelley Gondim for the support on species identification. This study was financed in part by the Coordenação de Aperfeiçoamento de Pessoal de Nível Superior, Brasil (CAPES) - Finance Code 001 [students: Carolina T. Puppin-Gonçalves and Sávio A.S.N. Moraes]. The National Council for Scientific and Technological Development $(\mathrm{CNPq})$ supported this work in part under scholarship [student Matheus A.L. Rocha] and CNPq/MPA [\#407046/2012-7]. Carlos E.R.D. Alencar was also supported by CNPq Post-doc scholarship [\#118801/2017-1].

\section{REFERENCES}

Alencar, C.E.R.D., Moraes, S.A.S.N., Araújo, P.V.N., Brito, V.L.G. \& Freire, F.A.M. 2013. New record of the blue swimming crab Callinectes sapidus Rathbun, 1896 (Crustacea: Portunidae) from the state of Rio Grande do Norte, northeastern Brazil. Check List, 9(6): 1567-1570.

Alencar, C.E.R.D., Moraes, A.B., Moraes, S.A.S.N., Araújo, P.V.N. \& Freire, F.A.M. 2014. First record of the association between the porcellanid crab Porcellana sayana and the brachyuran crab Stratiolibinia bellicosa. Marine Biodiversity Records, 7(82): 1-5.

Alencar, C.E.R.D., Vale, V.F., Moraes, S.A.S.N., Araújo, P.V.N. \& Freire, F.A.M. 2017. New record of the six- holed keyhole urchin, Leodia sexiesperforata (Leske, 1778) (Clypeasteroida, Mellitidae), from the Brazilian coast, with an updated distribution map. Check List, 13(5): 597-603.

Allen, J.D. \& Pechenik, J.A. 2010. Understanding the effects of low salinity on fertilization success and early development in the sand dollar Echinarachnius parma. Biological Bulletin, 218(2): 189-199.

Amaral, A.C.Z., Ribeiro, C.V., Mansur, M.C.D., Santos, S.B., Avelar, W.E.P., Matthews-Cascon, H., et al. 2008. Invertebrados aquáticos: a situação de ameaça dos invertebrados aquáticos no Brasil. In: Machado, A.B.M., Drummond, G.M. \& Paglia, A.P. (Eds.). Livro vermelho da fauna brasileira ameaçada de extinção. Ministério do Meio Ambiente, Brasília, pp. 156-165.

Brito, I.M. 1971. Contribuição ao conhecimento dos echinodermos da Ilha da Trindade, Brasil. Arquivos do Museu Nacional, 54: 261-265.

Clark, A.M \& Downey, M.E. 1992. Starfishes of the Atlantic. Chapman \& Hall, London.

Cowart, D.A., Ulrich, P.N., Miller, D.C. \& Marsh, A.G. 2009. Salinity sensitivity of early embryos of the Antarctic sea urchin, Sterechinus neumayeri. Polar Biology, 32: 435-441.

Fielding, A.H. \& Bell, J.F. 1997. A review of methods for the assessment of prediction errors in conservation presence/absence models. Environmental Conservation, 24: 38-49.

Forcucci, D. \& Lawrence, J.M. 1986. Effect of low salinity on the activity, feeding, growth and absorption efficiency of Luidia clathrata (Echinodermata: Asteroidea). Marine Biology, 92(3): 315-321.

Forward, R.B. \& Tankersley, R.A. 2001. Selective tidalstream transport of marine animals. Oceanography and Marine Biology: An Annual Review, 39: 305-353.

Fulan, J.A., Davason, R. \& Henry, R.A. 2009. Variação nictemeral das variáveis físicas e químicas da água influencia a abundância dos macroinvertebrados aquáticos. Revista Brasileira de Biociências, 7(2): 150-154.

Gómez, A. 1987. Estructura de la taxocenosis de peces en praderas de Thalassia testudinum de la bahía de Charagato, isla de Cubagua, Venezuela. Boletín del Instituto Oceanográfico de Venezuela, 26: 125-146.

Gondim, A.I., Christoffersen, M.L. \& Dias, T.L.P. 2014. Taxonomic guide and historical review of starfishes in northeastern Brazil (Echinodermata, Asteroidea). ZooKeys, 449: 1-56.

Gondim, A.I., Dias, T.L.P. \& Christoffersen, M.L. 2015. First record of basket stars Astrocyclus caecilian (Lütken, 1856) and Astrophyton muricatum (Lamarck, 1816) (Echinodermata, Ophiuroidea, Euryalida) for 
the state of Rio Grande do Norte, northeastern Brazil. Check List, 11: 1541.

Grünbaum, D. \& Strathmann, R.R. 2003. Form, performance, and trade-offs in swimming and stability of armed larvae. Journal of Marine Research, 61(5): 659-691.

Hadel, V.F., Monteiro, A.M.G., Ditadi, A.S.F., Thiago, C.G. \& Tommasi, L.R. 1999. Filo Echinodermata. In: Migotto, A.C. \& Thiago, C.G. (Eds.). Biodiversidade do Estado de São Paulo, Brasil: síntese do conhecimento ao final do século xx. Parte 3: invertebrados marinhos. FAPESP, São Paulo, pp. 260271.

Halpern, J.A. 1970. Growth rate of the tropical sea star Luidia senegalensis (Lamarck). Bulletin of Marine Science, 20(3): 626-633.

Helmuth, B. 2009. From cells to coastlines: how can we use physiology to forecast the impacts of climate change. Journal of Experimental Biology, 202(6): 753760.

Hijmans, R.J., Phillips, S., Leathwick, J. \& Elith, J. 2017. Dismo: Species Distribution Modeling, version 1.1-4. [http://rspatial.org/sdm/]. Reviewed: April 11, 2017.

Hyman, L.H. 1955. The invertebrates: Echinodermata. The coelomate bilateria. McGraw-Hill Book Company, London.

Krau, L. 1950. Observações sobre os Echinodermas da Baía de Guanabara. Memórias do Instituto Oswaldo Cruz, 48: 357-362.

Lawrence, J.M. 2013. Luidia. In: Lawrence, J.M. (Ed.). Starfish: biology and ecology of the Asteroidea. The Johns Hopkins University Press, Baltimore, pp. 109119.

Lawrence, J.M., Durán-Gonzáles, A., Solís-Marín, F.A., Herrera, J. \& Ventura, C.R.R. 2013. Distribution of Luidia clathrata and Luidia lawrencei (Echinodermata: Asteroidea) along the coast of the western Atlantic Ocean, the Gulf of Mexico and the Caribbean Sea. Cahiers de Biologie Marine, 54: 525-529.

Manso, C.L.C., Gondim, A.I. \& Ventura, C.R.R. 2014. New records of Ophiuroidea (Echinodermata) of the Brazilian coast, with notes on its taxonomy and distribution. Marine Biodiversity Records, 7(124): 17.

Manso, C.L.C., Alves, O.F.S. \& Martins, L.R. 2008. Echinodermata da Baía de Todos os Santos e da Baía de Aratu (Bahia, Brasil). Biota Neotropica, 8(3): 179196.

McClintock, J.B., Amsler, M.O., Angus, R.A., Challener, R.C., Schram, J.B., Amsler, C.D., Mah, C.L., Cuce, L. \& Baker, B.J. 2011. The Mg-calcite composition of Antarctic echinoderms: important implications for predicting the impacts of ocean acidification. Journal of Geology, 119(5): 457-466.

Moraes, S.A.S.N., Alencar, C.E.R.D., Thomsen, E. \& Freire, F.A.M. 2015. New records of the hairy crab Pilumnus dasypodus (Decapoda, Brachyura, Pilumnidae) in northeastern Brazil. Check List, 11(2): 1563.

Moura, M.S.B., Galvincio, J.D., Brito, L.T.L., Souza, L.S.B., Sá, I.I.S. \& Silva, T.G.F. 2007. Clima e água de chuva no semi-árido. In: Brito, L.T.L., Moura, M.S.B. \& Gama, G.F.B. (Eds.). Potencialidades da água de chuva no semiárido brasileiro. Embrapa Semiárido, Petrolina, pp. 35-59.

Netto, L.F., Hadel, V.F. \& Tiago, C.G. 2005. Echinodermata from São Sebastião Channel (São Paulo, Brazil). Revista de Biología Tropical, 53(3): 207-218.

Pawson, D.L. 2007. Phylum Echinodermata. Zootaxa, 1668: 749-764.

Phillips, S.J., Anderson, R.P. \& Schapire, R.E. 2006. Maximum entropy modeling of species geographic distributions. Ecological Modelling, 190: 231-259.

Phillips, S.J. \& Dudík, M. 2008. Modeling of species distributions with Maxent: new extensions and a comprehensive evaluation. Ecography, 31: 161-175.

R Core Team 2016. R: A language and environment for statistical computing. R Foundation for Statistical Computing, Vienna. [https://www.R-project. org]. Reviewed: April 11, 2017.

Rocha, L.A. 2003. Patterns of distribution and processes of speciation in Brazilian reef fishes. Journal of Biogeography, 3(8): 1161-1171.

Stickle, W.B. \& Diehl, W.J. 1987. Effects of salinity on echinoderms. Echinoderm Studies, 2: 235-285.

Spalding, M.D., Fox, H.E., Allen, G.R., Davidson, N., Ferdaña, Z.A., Finlayson, M., Halpern, B.S., Jorge, M.A., Lombana, A., Lourie, S.A., Martin, K.D., McManus, E., Molnar, J., Recchia, C.A. \& Robertson, J. 2007. Marine ecoregions of the world: a bioregionalization of coast and shelf areas. BioScience, 57: 573-583.

Stockwell, D.R.B. \& Peters, D. 1999. The GARP modeling system: problems and solutions to automated spatial prediction. International Journal of Geographical Information Science, 13(2): 143-158.

Towe, K.M. 1967. Echinoderm calcite: single crystal or polycrystalline aggregate. Science, 157(3792): 10481050.

Ventura, C.R.R., Lima, R.P.N., Nobre, C.C., Veríssimo, I. \& Zama, P.C. 2006. Filo Echinodermata. In: Lavrado, H.P. \& Ignácio, B.L. (Eds.). Biodiversidade bentônica da região central da Zona Econômica Exclusiva brasileira. Museu Nacional, Rio de Janeiro, pp. 339381. 
Ventura, C.R.R., Borges, M., Campos, L.S., CostaLotufo, L.V., Freire, C.A., Hadel, V.F., Manso, C.L.C., Silva, J.R.M.C., Tavares, Y. \& Tiago, C.G. 2013. Echinoderm from Brazil: historical research and the current state of biodiversity knowledge. In: Alvarado, J.J. \& Solis-Marin, F.A. (Eds.). Echinoderm research and diversity in Latin America. Springer, Berlin, pp. 301-344.

Received: 3 July 2019; Accepted: 31 January 2020 